\title{
Analyzing the Dynamical Factors of Housing Price in China
}

\author{
Weiping Huang ${ }^{1}$ \\ ${ }^{1}$ UNE Business School, University of New England, Armidale, Australia \\ Correspondence: Weiping Huang, UNE Business School, University of New England, Armidale, NSW 2351, \\ Australia. E-mail: cilla893@gmail.com \\ Received: February 10, 2014 \\ Accepted: February 26, 2014 \\ Online Published: March 2, 2014 \\ doi:10.5430/rwe.v5n1p59 \\ URL: http://dx.doi.org/10.5430/rwe.v5n1p59
}

\begin{abstract}
This study tries to explore the main dynamical factors on housing price in China based on various parameters and housing price models. Such parameters covers in this study are GDP, average housing area per person, average house price per meter square, Engel coefficient, etc. A number of data from a number of government departments, research organization and other resources (China Statistics Bureau, Statistical Commission, "Annual Statistical Report of China", "Annual Statistical Report of Chinese Cities", "Annual Report of Chinese Cities", "Annual Statistical Report of Real Estate in China) for establishing benchmarks. The major contribution of this study is to reveal an empirical analysis of the dynamical factors of housing price in China. It also can provide the high reference value for social and economic fields in China.
\end{abstract}

Keywords: housing price, housing cost, housing rental, house supply, house demand

\section{Introduction}

The broad area of study under which my proposal falls is in the area of the house prices in China. The thesis will examine the relationship between housing price and its six major dynamical factors (income, interest rate, credit reliability, tax structure, housing supply and population structure) in China.

The motivation behind this research is to provide the government with analytical approaches for the decision-making on housing policy. Besides, other parties concerned, such as real estate developing companies, banks, and city residents, can apply this study when they make decisions. Government, real estate developing companies, banks, and city residents need information that would assist them in the deployment of resources to ensure that they make right decisions according to scientific grounds and effective technical support. The lack of quantitative analysis and empirical study, and the resulting absence of reliable analyzing tools and modeling simulation have made it hardly possible for people to know clearly what factors of house price is sensitive to and how these factors influence house price which could bring negative effects on the healthy and sustainable development of the nation's house industry. Unfortunately, however, recent studies on the country's house market and house price have confined themselves to generate qualitative analysis. Therefore, it is very essential to establish an urban house price model which helps to analyze house investment and house policies based on a comprehensive study of the relations between house demand and house supply.

\section{Objectives of Study and Research Questions}

The aim of the study is to explore the concept of the dynamical factors of urban housing price and its functional mechanism in China by exploring the potential relationship between house price and its major dynamical factors. In addition one would seek to investigate the knowledge and data produced by a house price model, such as applicable regression models, filtrating model, stock-flow model, hedonic price methodology and Panel-data models based on empirical studies on statistics in a large numbers of cities and conclude by analyzing these model results for evaluating urban house price in China which consistent with the international experience in house price model and empirical studies.

The main research questions that the study would explore are:

- Is there any dynamical factor affecting urban house price. If yes, how can they work base on a house price model and empirical study?

- Do the financing effects impact on the desired residential house price after the introduction of house mortgage loan? 
If so, how? What is the internal matter?

- Can the house construction and installment cost influence on house price?

- Is there a relationship between land cost and house price?

- Is there a relationship between house rent and house price?

- How might the methodology be used to demonstrate above research questions?

\section{Background and Motivation}

Herbert Clark Hoover, who was a president of the United States of America, pointed out that nothing is more important than house for people's happy life and stable society. This information could influence positively the housing industry in every country in the world. This is why all the governments regard the housing improvement as a vital strategic status. Well development of house industry not only could active the economic growth effectively, but also could promote the sustainable and stable society. In turn, both the enhancement of habitation level and house construction are significant symbols of country development and society advancement.

In April 1981, the international conference of urban house and city issues in London announced "Declaration of the Rights of housing" that the well environment is suitable for people to live in, which is one of the basic human rights for all the residents, and every country is expected to become accountable to great housing supply. Furthermore, the second session of the United Nations Conference on human settlements in 1996 promised that everyone need to have suitable house which showed a beginning of house construction revolution to a great extent. These changes in basic principles have increased the importance of house for human being. We are witnessing a new phase in real estate development that is characterized by continuous revolution, the influence to people living condition, the relevance of nation and resident, the regulation and control of economy, and the prevalence of human factors. This new era presents significant challenges for real estate development direction and house policy by governments.

Reporting in this new environment has created a new research agenda. Over the years, several researchers (Geoffrey Meen, Mark Andrew and et al) have developed models for the evaluation of the dynamical factors of housing price such as income, interest rates, credit availability, tax structure, housing supply and demographic structure. However, there appears a gap in the literature. The researchers have not indicated whether there is an optimal mix of these dynamical factors to realize the rationality of house price and housing affordability in terms of profitability and sustainability. The purpose of my research is to extent the literature by providing literature on house price analysis in developed countries and the development of a model that can be used in China in determining an appropriate mixture of the major dynamical factors of house price to achieve the rationality of urban house price and housing affordability.

\section{Prior Research}

Both theoretical and empirical research has been undertaken on housing price in recent years. Early research focused on defining the housing price and on methods of its dynamical factors classification (e.g. Bartik, 1991; Poterba, 1991; Abraham and Hendershott, 1996). In 1991, Bartik, who is a forerunner in summarization and commentary of econometrics area, used the hysteresis-adjustment housing price model on empirical research for the first time. His result shows that population and employment influence the housing price differently (Bartik, 1991). Poterba studied the relationship between population, income, construction cost, aftertax use cost and housing price in 1991. He finds that the housing price is changed significantly by income and construction cost. Abraham and Hendershott also have developed a new housing price change model which is involved with the hysteresis concept. This model demonstrates the rise of housing price impacts on housing construction cost, employment rate and income directly. In addition, their analysis outcome has illustrated that the increase amplitude of house price is against the rise of interest rate (Abraham and Hendershott, 1996). Even though house pricing research has been performed in a variety of industries and with different perspectives, little research has been conducted on the action of population and aftertax use cost in developing countries, such as China.

Nigel Pain and Peter Westaway (1997) argue that the econometric model for house price analysis can be formulated from the maximize use model of standardized individual behavior, which is dissimilar from traditional methods and can be applied for long-term house demand directly (Westaway, 1992). One of the most important and widely referenced empirical researches which was adopted their model is the one by UK. Bank of England (1993). This study of ten major cities working on measuring housing price in last several decades found that resident migration was important for long-term real estate development. This study used statistical analysis of historical data to investigate the causal relationship between resident migration and house price change (Breedon and Joyce, 1993). 
The literature has identified a number of classification schemes, which divide the dynamical factors of urban housing price into the categories of population structure and resident income, rental, house location and financing effect (e.g. Bartik, 1991; Poterba, 1991; Ermisch et al, 1996; Nigel Pain and Peter Westaway, 1997; Geoff Kenny, 1999, Stuart A. Gabtiel et al, 2000, G. Donald and Daniel T. Winkler, 2001). One aspect of housing price that has received significant attention over the years is the area of its major factors. In 1998, Geoffrey Meen and Mark Andrew decided on both theory study and empirical research about the dynamical factors of housing price focusing on the literatures from America and British. Ludvigson and Steindel (1999) points out that lasting consumable can bring much larger fortune than income influence. However, house industry is a classical example. In 1998, Starr-McCluer provided support for fortune effect of the increased housing price which states that every 1-dollar rise in housing market can result in more than 7-cent in consumption every year. The second stage in housing price turned to the development of measurement models. Geoffrey Meen \& Mark Andrew (1998) indicated that there are two methods to research housing price. One is to use macroeconomics, such as life cycle model, which emphases the housing investment without space-latitude concept. The other is to apply urban economy theories which pay attention to space-centre concept, such as residential location theories. There exist four kinds of housing price model according to time order. The earliest model only involve limited variable, such as income. Make-up model is designed to demonstrate the relationship between housing price and construction cost. Simplified model is formulated from housing demand and housing supply. The last one is life cycle model. On the other hand, some researchers developed cointergration methods. These include Geoff Kenny's (1999) cointergration analysis skill and vector error correction model. These methods utilize data from house price, house stock, income and mortagage interest rate.

The literature has identified a number of methods for housing price expressions of different models in real estate market. Peter Westaway (1997) developed multiperiod model, which can also be namely life cycle model, is described as $\mathrm{HQ}_{\mathrm{d}}=\beta_{0}+\beta_{1}+\beta_{2} \mathrm{X}$. $\mathrm{HQ}_{\mathrm{d}}$ means housing demand quantity, HP means housing price, $\mathrm{X}$ means other demand variable and $\beta_{0}, \beta_{1}, \beta_{2}$ mean coefficient. This model consists of various characteristic of housing market, such as the relationship between income and the balance of housing mortagage loan, the relationship between saving and housing demand and the prediction of population variety. The other important model, which was studied by Poterba in 1984 , is housing supply adjustment model. Its formula is $\mathrm{HQ}_{\mathrm{s}}=\alpha(\mathrm{HP}-\mathrm{COST}) . \mathrm{HQ}_{\mathrm{s}}$ is housing supply quantity, $\alpha$ is coefficient which is more than 0 generally, HP is housing price and COST is housing cost which comprises land price, construction cost, management fee, finance cost and so on. This model implies that the strategic decision of real estate developing company need to comparing the housing price and housing cost. When housing demand number is equal to housing supply quantity, the new model can be draw as $\mathrm{HP}=f$ (X, COST), which was supposed by Geoff in 1999. Because of the different choices of X as factor variable, the multiplicate econometric model can be applied.

There is apparently, however, a considerable degree of concern that despite the progress taking place with regarding to the design of more effective function model, it still does not exist absolutely stable scale relationship between housing price and housing cost, since most real estate markets go against the long-term clearing price seriously (Geoff Kenny, 1999; Drake 1993, Wheeler and Chowdhury, 1993; Salo, 1994; Hafoort and Matysiak, 1997). There is a concern that the housing supply strategy is for short-term or long-term.

The literature has identified a number of methodologies for analyzing housing price change. The five more popular methodologies are stock-flow model, Tobit V Amemiya model, Panel-Date model, hedonic price methodology and hedonic method. The stock-flow model by DiPasquale and Wheaton (1996) makes a practical contribution to equilibrium modulation both for real estate property market and real estate asset market based on the variable of rental, housing price, planned construction quantity and housing stock quantity. Tobit V Amemiya model is a successful example demonstrating that housing expense determines the resident's choices on house purchase or house rent (Lee and Trost, 1978). BoKrsch-Supan and Pollakowski (1990) applied Panel-Date model on housing price analysis which used discrete selection model as emphases and polynomial logit as expressions. In 1967, Ridker and Henning behind Adelman and Griliches's initiatives (1961) sought for hedonic price expressions affecting housing price to point out that house environment has significant effect on housing price. By focusing on use factors, hedonic method emphasized different house characteristics affect the house quality (Wilkinson, 1973).

\section{Methodology}

The literature has identified a variety of research methodologies which were used (case study, questionnaire, survey of annual reports, interview, focus groups), the most popular being case study, to evaluate the dynamical factors of house price. Interviews and questionnaires were often used to supplement each other. Given this background, I proposed to use an econometric approach drawing on qualitative and quantitative research methods. The ultimate 
objective could be a qualitative score or index that can be manipulated, however the process of building the index would require that components of urban house price are be measured and valued. Also this is often a highly subjective exercise requiring input from several different perspectives.

The steps that would be taken would include a series of qualitative literature to identify the components of urban house price that are applicable to the real estate industry. Using the information provided from the case studies together researched by Geoff Kenny (1999), Muth (1969), Follain (1979), Poterba (1984), Stover (1986) and Malqezzi and Maclennan (1996) develop a set of constructs that house price is determined by house demand and house supply. Therefore, a model establishment between house demand and house supply for housing market will be consilient to this research using multiperiod model which can also be namely life cycle model (Peter Westaway, 1997) and housing supply adjustment model (Poterba, 1984). The questionnaire and annual report survey that would be used to evaluate house price would consist of statements that aim to operationalize and reflect the constructs mentioned. In addition, these statements would be weighted according to their importance and relevance for optimizing the relationship between real estate development companies and consumers. This questionnaire would be piloted, refined and administered and the annual report survey would be official by government.

The data would be recoded to reflect scores and indices in most of major cities in China, such as GDP, average housing area per person, average house price per meter square, Engel coefficient, etc. The proposed indices would be presented to a range of cities for theoretical and empirical study. Data from the urban real estate market both financial and operational would be collected. The data on analyzing measures would be cross-referenced to data from a number of government departments, research organization and other resources (China Statistics Bureau, Statistical Commission, "Annual Statistical Report of China", "Annual Statistical Report of Chinese Cities", "Annual Report of Chinese Cities", "Annual Statistical Report of Real Estate in China) for establishing benchmarks. The final step would be to present case studies employing indices as developed. In using case studies, a sample of house price analysis would be used to test the model using technique for measuring reasonableness and sustainment such as econometrics analysis.

\section{Hypotheses}

Somerville and Mayer (2000) research that the increase of housing supply quantity is highly related with the rise of housing price and construction cost. However, in the short time, the trend of urban housing price will be determined by housing demand factor. Therefore, hypotheses one can be established that housing construction cost is a major dynamical factor of housing price in the long time instead of short time. If hypotheses one is tenable, the other hypotheses can be processed that land price does not impact on housing price significantly in long time. Contrarily, land price is one of major dynamical factors for single real estate development program.

\section{Findings}

In theory, land cost is not a vital factor which can decide urban house price. To some extent, land price can be conceived as something which derive from the interactions of house demand and house supply. When it is seen as a single element of enforcing a house project, however, it is still a very important dynamical factor. For example, according to the empirical analysis of the 90 urban building on sale in China in 2013, the estimated elasticity coefficient of land cost amounts to 0.351 and the illustrative power of land cost reaches $60.9 \%$ which means that every $1 \%$ change in the land cost will lead to a corresponding change of $0.351 \%$ in housing price. Therefore, in terms of specific project cases, land cost is one of major motivating factors of housing price in China.

Table 1. Theoretical housing price vs. actual housing price of 5 major cities in China in 2013

\begin{tabular}{lrrrrr}
\hline & Beijing & Shanghai & Guangzhou & Hangzhou & \multicolumn{1}{c}{ Shenzhen } \\
\hline $\begin{array}{l}\text { Theoretical Housing Price } \\
\text { (RMB/m2) }\end{array}$ & 21,216 & 22,884 & 25,842 & 18,186 & 36,000 \\
\hline & 28,296 & 21,954 & 24,282 & 23,976 & 33,102 \\
\hline $\begin{array}{l}\text { Actual Housing Price (RMB/m2) } \\
\text { Error Rate }\end{array}$ & $28.60 \%$ & $-3.03 \%$ & $-7.03 \%$ & $30.65 \%$ & $-7.94 \%$ \\
\hline
\end{tabular}

Table 1 presents some descriptive statistics of housing price of 5 major cities in China in 2013, which are used in this study, such as Beijing, Shanghai, Guangzhou, Shenzhen and Hangzhou. We can find that the error rates of Shanghai, Guangzhou and Shenzhen are less than 10\%. But the error rates of Beijing and Hangzhou are higher than 30\% which means the housing prices of these two cities have exceptional alteration. It also can be considered that other factors 
influence the actual housing prices in those two local areas, such as local population structure, real GDP per capita and per capita disposable income.

\section{Conclusion}

The contribution that this research should make is extending the literature on urban real estate in developing countries such as China as they developed rapidly in the last several decades including real estate industry and whether this rapid increase of urban housing price was reasonable and sustainable. This research finding should also assist them in government's regulation and control in economy, business management, bank management of credit, national and international investment, and deployment of other resources to ensure that they are positive. This research should also contribute to the extant literature by providing a model for evaluating urban housing price in the real estate industry.

\section{References}

Abraham, J.M., \& Hendershott, P.H. (1996). Bubbles in Metropolitan Housing Market. Journal of Housing Research, 7(2), 191-208.

Alma, J., \& J.R. Jr. Follain. (1983). Alternative mortgage instruments: their effects on consumer housing choices in an inflationary environment. Public Finance Quarterly, 35, 67-77.

Amemiya, T. (1984). Tobit models: a survey. Journal of Econometrics, 24, 3-63. http://dx.doi.org/10.1016/0304-4076(84)90074-5

Andrews, D., \& Schafgans, M. (1998). Semiparametric estimation of a sample selection model. Review of Economic Studies, 65, 497-518.

Bartik, T.J. (1991). Who Benefits from State and Local Economic Development Policies? Kalamazoo, Michigan, USA: Upjohn Institute.

BoKrsch-Supan, A. (1986). Household Formation, household prices and public policy impacts. Journal of Public Economics, 25, 145-164.

BoKrsch-Supan, A. (1987). Econometric Analysis of Discrete Choice: with Applica-tions on the Demand for Housing in the US and Germany. Berlin, German: Springer University.

BorKrsch-Supan, A., \& Pollakowski, H.O. (1990). Estimating housing consumption adjustments from panel data. Journal of Urban Economics, 27, 131-150. http://dx.doi.org/10.1016/0094-1190(90)90011-B

Breedon, F.J., \& Joyce, M.A.S. (1993). House prices, arrears and possessions: a three equation model for the UK. Bank of England Working Paper, 14.

Donald, G. J., \& Daniel, T. W. (2001). The dynamics of metropolitan housing price. Journal of Urban Economics, 54, $32-44$.

Drake, L. (1993). Modelling UK house prices using cointegration: an application of the Johansen technique. Appied Economics, 25, 1225-1228.

Ermisch, J.F., Findlay, J., \& Gibb, K. (1996). The price elasticity of housing demand inBritain: issues of sample selection. Journal of Housing Economics, 5, 64-86. http://dx.doi.org/10.1006/jhec.1996.0004

Geoff, K. (1999). Modeling the demand and supply side of the housing market: evidence from Ireland. Economic Modeling, 16, 389-409.

Geoffrey M., \& Mark A. (2000). Modelling Regional House Prices: A Review of the Literature. USA: The Centre for Spatial and Real Estate Economics. Department of Economics, The University of Reading.

Hendershott, P.H. (1991). Are real house prices likely to decline by 47 percent? Regional Science and Urban Economics, 21, 553-563.

Muth, R.F. (1969). Cities and Housing. Chicago, USA: University of Chicago Press.

Muth, R.F. (1986). Exceptions of house price changes. Paper of Regional Science Association, 59, 45-55.

Pain. N., \& Westaway, P.F. (1994). Housing, consumption and borrowing: an econometric model of personal sector behavior. Government Economic Service Working Paper, 123, 9-13.

Pain. N., \& Westaway, P.F. (1996). Modelling structural change in the UK housing market: a comparison of alternative house price models. NIESR Discussion Paper, 91, 11-16. 
Patric H. H. (1997). Uses of equilibrium models in real estate research. Journal of Property Research, 14, 1-13. http://dx.doi.org/10.1080/095999197368726

Porterba, J.M. (1984). Tax subsidies to owner-occupied housing: an asset market approach. Q.J. Economics, 99, 729-752. http://dx.doi.org/10.2307/1883123

Porterba, J.M. (1991). House price dynamics: the role of tax policy and demographics. Brookings Papers on Economic Activity, 2, 143-204.

Porterba, J.M. (2000). Stock Market Wealth and Consumption. The Journal of Economic Perspectives, 14(2), 99-118. http://dx.doi.org/10.1257/jep.14.2.99

Salo, S. (1994). Modelling the Finnish housing market. Econometric Model, 11, 250-265.

Starr-McCluer, M. (1998). Stock Market Wealth and Consumer Spending. Working paper, Federal Reserve Board of Governors. http://dx.doi.org/10.1257/jep.14.2.99

Westaway, P.F. (1992). A simulation model of consumer spending and housing demand. NIESR Discussion Paper, 15, 4-11.

Wheaton, W. C. (1996). Vacancy, search, and prices in a housing market matching model. Journal of Political Economy, 98, 1270-1292. http://dx.doi.org/10.1086/261734 